\title{
Low carbohydrate-high protein diets
}

\author{
Short term benefits of weight loss seem outweighed by longer term cardiovascular harms
}

\author{
Anna Floegel nutritional epidemiologist ${ }^{1}$, Tobias Pischon professor ${ }^{2}$ \\ ${ }^{1}$ Department of Epidemiology, German Institute of Human Nutrition Potsdam-Rehbruecke, 14558 Nuthetal, Germany; ${ }^{2}$ Molecular Epidemiology \\ Group, Max Delbrück Center for Molecular Medicine Berlin-Buch, Berlin, Germany
}

Low carbohydrate-high protein diets and their combinations (such as the Atkins diet) have become popular worldwide and are frequently adopted for weight control by lay people. These diets have also been suggested to have health benefits over low fat diets, mainly on the basis of results from short term intervention studies. These benefits include reductions in plasma triglyceride, glycated haemoglobin, and insulin concentrations as well as in systolic blood pressure, ${ }^{1-3}$ with consequent improvements in conditions such as type 2 diabetes and non-alcoholic steatohepatitis. ${ }^{4}$ However, the long term health effects of low carbohydrate-high protein diets are unclear, particularly as adherence to them has been associated with higher mortality from cardiovascular diseases in prospective cohort studies. ${ }^{5-7}$ These conflicting results have fostered a debate over the benefits and risks of such diets. ${ }^{4}$

In the linked article (doi:10.1136/bmj.e4026), Lagiou and colleagues investigated the association between adherence to low carbohydrate-high protein diets and the incidence of cardiovascular disease in a prospective cohort of $43<$ thin $>396$ Swedish women followed for an average of 15.7 years. ${ }^{8}$ They looked for a diagnosis of incident cardiovascular disease, including ischaemic heart disease, ischaemic or haemorrhagic stroke, subarachnoid haemorrhage, or peripheral arterial disease. The women's habitual diet was assessed by use of food frequency questionnaires at baseline, and participants were grouped according to the macronutrient composition of their diets into tenths of low carbohydrate, high protein, and low carbohydrate plus high protein intake. Stronger adherence to any of these dietary patterns was consistently associated with a higher incidence of cardiovascular disease in a dose-response manner and independently of common risk factors. In particular, women had a $5 \%$ higher incidence of cardiovascular disease for each tenth of an increase in the low carbohydrate-high protein score, yielding a $62 \%$ higher incidence among women in the highest categories of low carbohydrate-high protein diets compared with the lowest.

In the context of previous studies,${ }^{5-7}$ Lagiou and colleagues provide further evidence that challenges the safety of long term adherence to low carbohydrate-high protein diets. ${ }^{8}$ Although these results are based on an observational study, their biological plausibility seems self evident. A low carbohydrate diet implies low consumption of wholegrain foods, fruits, and starchy vegetables and consequently reduced intake of fibre, vitamins, and minerals. A high protein diet may indicate higher intake of red and processed meat and thus higher intake of iron, cholesterol, and saturated fat. These single factors have previously been linked to a higher risk of major chronic diseases, including cardiovascular disease, in observational studies, ${ }^{9}$ so it is not surprising that this combination of risk factors is linked to a higher incidence of disease and mortality.

As a consequence, long term adherence to low carbohydrate-high protein diets would require careful food choices, such as increased consumption of proteins from vegetables and cautious monitoring of saturated versus unsaturated fat intake, to avoid unfavourable eating patterns. This problem becomes even more challenging considering that these types of diets are mainly targeted at overweight and obese people, whose diets tend to be of lower quality. In addition, the higher incidence of cardiovascular disease in people following low carbohydrate-high protein diets was seen consistently across different protein sources and when adjusted for fat quality. ${ }^{8}$ This further highlights the role of other factors not adjusted for by the authors, such as intake of fruits, vegetables, and fibre, and illustrates the complexity of these unfavourable eating patterns that may result from such diets.

A multinational randomised controlled trial recently found that adherence to a high protein diet reduced body weight but did not improve intermediary cardiovascular phenotypes. ${ }^{10}{ }^{11}$ In the same study, adherence to a low glycaemic index and low protein diet improved cardiovascular disease risk markers in addition to reducing body weight. In this context, Lagiou and colleagues' study may ring the bell for a new round in the scientific debate on the usefulness of low carbohydrate-high protein diets. ${ }^{8}$

Despite the popularity of these diets, clinicians should probably advise against their use for long term control of body weight. The European Society of Cardiology recommends high intakes of fruits, vegetables, and wholegrain products and reduced fat intake, ${ }^{12}$ a pattern unlikely to fit low carbohydrate-high protein diets. Even in the highest categories of low carbohydrate-high protein diet the women in the current study did not yet reach 
the low carbohydrate and high protein content recommended by commercial diets. ${ }^{8}$ Considering the observed dose-response relation, we may assume that an even higher incidence of cardiovascular disease would be associated with full adherence to commercial diets.

The discrepancy between conclusions derived from short term intervention trials and those from long term survival studies needs to be resolved before low carbohydrate-high protein diets can safely be recommended to patients. But in the meantime, the short term benefits of low carbohydrate-high protein diets for weight loss that have made these diets appealing seem irrelevant in the face of increasing evidence of higher morbidity and mortality from cardiovascular diseases in the long term.

Competing interests: Both authors have completed the ICMJE uniform disclosure form at www.icmje.org/coi_disclosure.pdf (available on request from the corresponding author) and declare: no support from any organisation for the submitted work; no financial relationships with any organisations that might have an interest in the submitted work in the previous three years; no other relationships or activities that could appear to have influenced the submitted work.

Provenance and peer review: Commissioned; not externally peer reviewed.

Hession M, Rolland C, Kulkarni U, Wise A, Broom J. Systematic review of randomized controlled trials of low-carbohydrate vs. low-fat/low-calorie diets in the management of controlled trials of low-carbohydrate vs. low-fat/low-caloried
obesity and its comorbidities. Obes Rev 2009;10:36-50.
2 Shai I, Schwarzfuchs D, Henkin Y, Shahar DR, Witkow S, Greenberg I, et al. Weight loss with a low-carbohydrate, Mediterranean, or low-fat diet. N Engl J Med 2008:359:229-41.

3 Sacks FM, Bray GA, Carey VJ, Smith SR, Ryan DH, Anton SD, et al. Comparison of weight-loss diets with different compositions of fat, protein, and carbohydrates. N Engl J Med 2009;360:859-73.

4 Frigolet ME, Ramos Barragan VE, Tamez Gonzalez M. Low-carbohydrate diets: a matte of love or hate. Ann Nutr Metab 2011;58:320-34.

5 Fung TT, van Dam RM, Hankinson SE, Stampfer M, Willett WC, Hu FB. Low-carbohydrate diets and all-cause and cause-specific mortality: two cohort studies. Ann Intern Med 2010;153:289-98.

6 Lagiou P, Sandin S, Weiderpass E, Lagiou A, Mucci L, Trichopoulos D, et al. Low carbohydrate-high protein diet and mortality in a cohort of Swedish women. J Intern Med 2007;261:366-74.

7 Trichopoulou A, Psaltopoulou T, Orfanos P, Hsieh CC, Trichopoulos D. Low-carbohydrate-high-protein diet and long-term survival in a general population cohort. Eur J Clin Nutr 2007;61:575-81.

8 Lagiou P, Sandin S, Lof M, Trichopoulos D, Adami H-O, Weiderpass E. Low carbohydrate-high protein diet and incidence of cardiocasvular diseases in Swedish women: prospective cohort study. BMJ 2012;344:e4026.

9 McCullough ML, Feskanich D, Stampfer MJ, Giovannucci EL, Rimm EB, Hu FB, et al. Diet quality and major chronic disease risk in men and women: moving toward improved dietary guidance. Am J Clin Nutr 2002;76:1261-71.

10 Gogebakan O, Kohl A, Osterhoff MA, van Baak MA, Jebb SA, Papadaki A, et al. Effects of weight loss and long-term weight maintenance with diets varying in protein and glycemic index on cardiovascular risk factors: the diet, obesity, and genes (DiOGenes) study: a randomized, controlled trial. Circulation 2011:124:2829-38.

11 Larsen TM, Dalskov SM, van Baak M, Jebb SA, Papadaki A, Pfeiffer AF, et al. Diets with high or low protein content and glycemic index for weight-loss maintenance. $N$ Engl $J$ Med 2010;363:2102-13.

12 Graham I, Atar D, Borch-Johnsen K, Boysen G, Burell G, Cifkova R, et al. European guidelines on cardiovascular disease prevention in clinical practice: executive summary. Fourth Joint Task Force of the European Society of Cardiology and other societies on cardiovascular disease prevention in clinical practice (constituted by representatives of nine societies and by invited experts). Eur J Cardiovasc Prev Rehabil 2007;14(suppl 2): E1-40

Cite this as: BMJ 2012;344:e3801

(c) BMJ Publishing Group Ltd 2012 